HStud 24 (2010)2, 189-213 DOI: 10.1556/HStud.24.2010.2.3

\title{
CATHOLIC IDENTITY IN HUNGARY - THE MINDSZENTY CASE
}

\author{
ÁRPÁD V. KLIMÓ \\ University of Pittsburgh, Pittsburgh, PA \\ USA
}

\begin{abstract}
At first glance, the Catholic identity of a Cardinal should not be a complicated topic, particularly if we are dealing with a person who became one of the most famous symbols of Catholic resistance against communism during the Cold War Era. In the 1950s Cardinal József Mindszenty was regarded as one of the most prominent martyrs of the Catholic Church. This reputation emerged again in the early 1970s all over the world, particularly in North and South America, but also in Western Europe, Austria, and Germany. He was arrested, put on trial in 1949, imprisoned, allegedly tortured, was freed during the revolution of 1956, and spent the next 15 years of his life as an exile in the U. S. Embassy in Budapest. He died only four years later, in 1975, in his last exile in Vienna. But József Mindszenty, born József Pehm in 1892, stood also for a very specific understanding of Hungarian Catholicism: a particularly conservative, anti-liberal, legitimist, pre-Vatican II, reactionary, traditionalist and nationalist Catholicism. In my paper, I look at the case of Cardinal Mindszenty in order to explore the most important aspects and changes of Hungarian Catholic identity during the 20th century. I want to show that, contrary to the common view, most questions regarding Mindszenty and Hungarian Catholicism are still open and require further research.
\end{abstract}

Keywords: Hungarian National identity, Catholicism, Cardinal Mindszenty, Cold War

\section{Introduction: The Complexities of "Catholic identities"}

We should first address the general notion of "identity," which is a concept that is constantly debated and therefore needs to be defined. It derives from the Latin "idem" and basically means that a person, group, or thing stays "the same" over time. "Identity" is here understood as a system of references used to describe the relationship between a person and a group as a constant set of attributes (for a critique of the concept see Geulen, 1999; Niethammer, 2000, and Niethammer, 2003). These references or points of reference consist of spatial and temporal representations. Personal as well as collective identities are constructed around local 
and national master narratives, and these are related to wider and deeper spatial and temporal, social and cultural representations. Identity, therefore, describes a process of attempts to create a coherent, continuous narrative about the self based on the idea of continuity in space and time, on differences and boundaries with regard to other identities, but also on communalities with regard to other identities. Each group is part of other, larger groups on a higher territorial and cultural level: European nations always define their place with regard to "Europe" as a whole, whereby "Europe" is also constructed in a way that fits the necessities of this particular group identity (af Malmborg and Stråth, 2002, 1-25). Identities "function" if there are enough people who believe in their existence, even if the ideas related to these constructs are self-contradictory.

"Catholic identity" is particularly difficult to define. Many, but not all, Catholics identify with their church and with some basic elements of the church's teachings and institutions, particularly the extraordinary role the clergy plays, from the parish priest and the local bishop to the very top of the hierarchy, the bishop of Rome, as head of the universal church. Very often the cult of Saint Mary and/or of other saints, often local or regional saints, or of saints related to certain professions or occupations or saints that help in specific difficult situations are equally part of "Catholic identities." The major problem with all these aspects of Catholicism and Catholic life is that they can differ strongly depending on the various local, regional, national or continental conditions and contexts. There are so many different ways of defining Catholic manners of thinking and acting that we have to begin with specific cases before we can reach more general conclusions regarding the question of a Catholic identity.

According to Ian Linden, Catholicism consists of at least four different churches. The first is the community of 1.3 billion Catholics in the world, the second is a theological construct of a church led by the Holy Spirit, which exists inside the world and history and at the same time transcends them both; the third is a hierarchical institution lead by the Roman bureaucracy around the Pope and the Curia; and, finally, the fourth is the church as it is seen from outside the church (Linden, 2009, 1-2).

When looking at Hungarian Catholic identities in the 20th century, we must keep in mind this complexity. Being a Hungarian Catholic can mean totally different things to believers in a small village, a provincial town, or Budapest, not to mention to a bishop or a cardinal. These different meanings are produced by their encounters, conflicts and experiences with their environment. 


\section{Catholic Identity and Christian Nationalism in Provincial Hungary: Mindszenty (Pehm) in Zalaegerszeg, 1919-41}

József Pehm was born in the small village Csehimindszent (which means "Czech Mindszent") to a Catholic peasant family in the south-western part of Hungary, only about $40 \mathrm{~km}$ east of the Austrian border. He himself related his family and his village of birth to spatial and temporal representations of much larger entities, such as the history of the Hungarian nation and the history of Europe as a continent shaped by Latin Christianity.

In his memoirs, Mindszenty refers to the close relationship between his own personal fate and that of the Hungarian nation. This identification is related to a well established historical narrative of Hungary's victimization, starting in the 19th century and renewed after the Trianon Treaty of 1920 and the anti-Stalinist Uprising of 1956. According to this narrative, Hungarians are a suffering people, a martyred nation. Correspondingly, German Nazism and anti-Semitism and "Russian" Communism are represented as forces foreign to "Hungarianness." All negative aspects of Hungarian history and society are externalized. Mindszenty would often refer to this narrative in his speeches, appending his view, according to which Hungarians have nothing to fear as long as they stay loyal to the Catholic Church and the Holy Virgin, the Patron Saint of the country.

Mindszenty's concept of Hungarian history also resembles some of the ideas developed by Hungarian Catholic historian Gyula Szekfü in his very influential book Three Generations. This work is considered to be one of the major intellectual contributions to Hungarian Christian nationalism of the interwar period. It narrates the history of Hungary between 1848 and 1918 as a period of decline, blaming "foreign" liberalism as the main cause for Hungary's difficult situation in the years after 1919 (Szekfü, 1920). Many Catholics hoped that Christian nationalism could become the instrument that would overcome the legacy of 19th century liberalism in Hungary, which was regarded as the driving force behind secular modernity (Hanebrink, 2009). Like Catholics in other countries in Europe and the USA, however, they were still caught inside the fortress mentality they had adopted in the 19th century, when liberalism and other modern ideologies succeeded in diminishing the influence of the Church in many fields, particularly regarding the family (the introduction of civil marriage, for instance) and the role of religion in society (emancipation of Protestantism and Judaism). On the other hand, the Catholic renaissance, the successes of Catholic parties and trade unions, the thriving of religious orders and Catholic associations nourished the hope for a re-Christianization of society.

From this perspective, Mindszenty drew a parallel between the interwar-year situation and the end of Turkish occupation. In 1934 he wrote a biography of Bishop Márton Biró of Veszprem who, in the mid-18th century, had restructured 
the diocese after the end of the Turkish invasion. When Mindszenty became parish priest of the town of Zalaegerszeg, he had to connect himself with the legacy of Biró:

\begin{abstract}
During the following one hundred and fifty years up to the time I took office in 1919, there had been only slight changes in the parish. My aim was to create a contemporary parish life. [...] What I learned in the course of my research about the reconstruction after the Turkish occupation proved highly suggestive to me in my own work. I felt I had been summoned, after one hundred and fifty years, to launch a comparable campaign of reconstruction, first in Zalaegerszeg; and then, after 1927, in Zala County; and still later throughout the large diocese of Veszprém (Mindszenty, 1974, 10f.).
\end{abstract}

The name of his native village points to another important aspect: the ethnic complexity of his regional background, where Hungarians lived alongside Germans (often referred to as "Swabians"), Croats, Slovenes, Serbs and others without any clear ethnic selfunderstanding. Beginning in the late 18th century, when the Habsburg Empire underwent a radical shift and national movements developed, these ethnic options, which for the most part had not been clearly formulated or articulated, became strongly politicized. The region itself(Vas county) remained overwhelmingly Catholic, because it had fallen within the realm of the Habsburgs in the 16th century, a time when other parts of Hungary had either been occupied by the Turkish forces and transformed into a part of the Ottoman Empire or had been independent, as in the case of the Principality of Transylvania. In both these regions, which were outside the reach of the Habsburg Empire for some 150 years, Protestantism thrived and challenged Catholic hegemony. When the Hungarian national movement became very strong around the middle of the 19th century, many Protestants combined the struggle for national independence with the emancipation of their denomination from Habsburg and Catholic domination. Like Prussia, Switzerland or the Netherlands, the modern idea of the nation related liberalism to Protestantism and excluded Catholics. Catholicism was constructed as the Other in this modern Hungarian national master narrative. Catholicism as the Other combined four different dimensions:

(1) Political dimension: the Catholic Church was identified with the Habsburg monarchy as the "foreign" ruling house, particularly during and after the revolution of 1848/49. One "proof" of this was the pro-Habsburg loyalty shown by some bishops, including the archbishop of Esztergom, János Hám. Protestants also seemed to be overrepresented among the leading revolutionaries of 1848. This simplified view ignored the fact that many Catholics, including some bishops and priests, were persecuted by the Austrian military authorities because of their revolutionary activities. 
(2) Social dimension: the Catholic Church was identified with the upper, more European and cosmopolitan aristocracy of Hungary, while Calvinists were overrepresented among the lower nobility, the Gentry (dzsentri). The latter understood itself as the very essence of Hungarianness.

(3) Ethnic dimension: as a confessional group, Catholics consisted of the highest number of different ethnic groups in the Hungarian Kingdom, including Croats, Germans, Romanians (Uniates), Slovaks, Slovenes, and Ukrainians (Catholic Orthodox or Uniates), while the members of the Reformed church were roughly 90 per cent ethnic Magyars. This argument gathered strength towards the end of the 19th century, when racist ideas began to spread ever more quickly in Central Europe.

(4) Cultural dimension: The denominational differences in Hungary were also connected to ways of living, dress, music, food, etc. The Hungarian language has even two different words for "Christian": the Catholic word keresztény and the word keresztyén, used by Protestants.

Mindszenty offers a good case study for exploration of the complexities of Hungarian Catholic identity not only because of his background, but also because of the political prominence he achieved. He himself rejected the role of a "political priest" who would act within a political party or in institutions such as parliament but he was definitely a "politicizing priest." Mindszenty tried to characterize his political engagement in a manner that would make it acceptable to the ideas of Pope Pius XI, who condemned the politically active priest and favored activities of laymen controlled and directed by priests according to the ideal of Catholic Action (Ubi Arcano Dei, 1922):

I became a member of the County and Town Council, and as a result, I naturally became more involved in public life. [...] Although I fully supported the political activities of Bishop Ottokár Prohászka and other clerics under exceptional circumstances, I myself firmly refused when my friends wanted to nominate me, because I had never thought very highly of the role of the priest-politician. I was all the more determined to fight the enemies of my country and Church with the written and spoken word, and to support all Christian politicians by giving clear and decisive directives to the faithful. But I myself wanted simply to remain a pastor. I regarded politics as a necessary evil in the life of a priest. [...] It would certainly be a sign of great weakness if a priest were to leave vital political and moral decisions solely to the often misled consciences of the laity (Mindszenty, 1974, 10-11).

Mindszenty's career did not suffer from his strong standpoints in political conflicts. Indeed it may well have profited from them. Twice he was promoted after 
having been imprisoned. The first arrest happened immediately after the end of the First World War and the breakdown of the Habsburg Empire. As a young priest and teacher in the small town of Zalaegerszeg he began to write articles criticizing the new liberal-democratic regime of Mihály Károlyi, which came to power in November 1918. A provincial representative of the new government who seemed not to be used to a free press had József Pehm arrested. The radical socialist regime of the "Councils Republic" which rose to power in the wake of the fall of the Károlyi government detained the young priest again, but could not enforce his imprisonment. Shortly after this incident, József Pehm was appointed to parish priest of Zalaegerszeg. It seems as if his engagement against the new order was appreciated by his church superiors. With him, the church could also present a priest who had openly resisted both revolutions, which in the context of the nationalist Horthy regime were interpreted as the most horrible incidents of Hungarian history. Fifteen years later, József Mindszenty, then bishop of Veszprém, was arrested by Arrow Cross representatives. After he was released from prison, he was again seen as a courageous fighter for the church and someone who had resisted a terrible regime. He became head of the Catholic Church in Hungary and Pius XII made him a cardinal.

József Pehm supported the Horthy regime and "Christian nationalism" only to a certain extent. He remained loyal to King Charles IV, which was also a characteristic common to his native region in south western Hungary. Until at least 1937 Pehm backed the legitimist Catholic People's Party against the National Unity Party, which was supported with all means by the central government in Budapest. It would be too simple to understand Pehm/Mindszenty only as a conservative, anti-modern, anti-liberal, legitimist priest who was politically active. As parish priest of Zalaegerszeg and as bishop of Veszprém in 1943-45 he was engaged in numerous social and educational reforms. In his district Catholic Action, the new centralized association of various Catholic lay organizations (though strongly controlled by the clergy) founded in Hungary in 1932, was thriving, and many new schools were built. Pehm/Mindszenty belonged to a new generation of active priests who engaged in various reforms and in the modernization of Catholicism in different fields. Although he didn't officially belong to a party, he was active in support of "his" Christian People's Party from his position as a priest who hoped for a re-Christianization of Hungarian society.

\section{Difficult Questions Concerning War and Genocide: József Mindszenty (Pehm), 1941-45}

Hungarian Catholicism was not well prepared for what was to follow the interwar years, which included a focus on re-Christianization, the fortress mentality, 
and cultural antisemitism (I use this spelling deliberately, as I feel it makes little sense to hyphenate the term; there is no such thing as "Semitism," Antisemitism exists as an ideology and way of thinking on its own terms, not in relation to something else). Antisemitism was inherent in Christian nationalism and had been a part of Catholic anti-liberalism since the 1890 s, preventing the church from becoming a strong antifascist force and instead contributed to making antisemitism socially acceptable in Hungary (Hanebrink, 2009). The fine distinction between "cultural" and "racial" antisemitism drawn by the Church did not seem to be clear to many people.

Many scholars talk about the "failure" of the Pope and the Catholic Church during World War II and the Holocaust, but I think we should speak rather about the weakness of the Church, which became obvious during these years. The Pope tried to prevent the war and he deplored the atrocities that took place between 1939 and 1945, including the Holocaust. Instead of a re-Christianized society in Europe there were millions of Catholics who did not follow the Pope, but rather remained helpless or trapped in their own nationalisms. Catholics still lived in their ghettos, though they had gained some ground in society. Even in France, where the Catholics were to a certain extent reintegrated into the nation under the promises of summer 1914, into the "Union Sacrée," the integration came at a high price: Catholics had to embrace modern nationalism. Some Catholics used antisemitism to express their rejection of modern society. In Hungary they were trapped in "Christian nationalism," which was created under the influence of some eminent Catholic intellectuals after 1919, including Ottokár Prohászka, Béla Bangha, and others.

What was Jozsef Pehm/Mindszenty's role during the most horrible period of Hungarian and European history in the 20th century? This is a question that still awaits further research (Hóbor, 1997). We know very little about the newspaper ("Zalamegyei Újság") he owned as head of the local church: was it antisemitic, like other Catholic papers? If so, was it more or less antisemitic than other papers? In 1935 the paper and Pehm himself supported the candidate of the Catholic People's Party, which was also Mindszenty's party (Paksy, 2004). Tibor Boldogfai Farkas (1883-1940), an aristocratic landowner and a legitimist member of parliament since 1922, criticized the antisemitic propaganda of the Arrow Cross and other right-wing movements. Pehm/Mindszenty was also active in the field of revisionism regarding the Trianon treaty, particularly after the defeat of Yugoslavia in 1941, when some formerly Hungarian territories were reintegrated to the county of Zala (Göncz, 2005).

But Pehm's standpoint regarding Nazism, antisemitism, and the Arrow Cross movement, and the standpoint of Hungarian Catholicism in general, was more ambivalent. A document from 1938, which was used during the Communist show trial, indicates that Pehm convoked a meeting of priests in Budapest which dis- 
cussed not only the possibilities of connecting social reforms with the "Jewish question," but also the option of reducing the distance of the church from the Arrow Cross party (Hanebrink, 2009, 156). The meeting does not seem to have had any major consequences.

Two years later, in 1940, József Pehm was asked by Prime Minister Pál Teleki to organize the "National-political Service" in the Transdanubian region in south-western Hungary. The goal of this movement was to counterbalance Nazi influence, which was gaining momentum at the time among members of the Hungarian German population. In 1942, after Teleki had committed suicide in the wake of Horthy's decision to go to war against Yugoslavia and the Soviet Union on the side of Germany, József Pehm changed his German sounding name to Mindszenty. Some of his supporters have argued that the magyarization of his name was a protest against the Germans (Csonka, 1976, 9). In his memoirs he does not even mention the changing of his family name, which is astonishing. He even insists on the "Hungarianness" of his whole family, as if he wanted to defend himself against accusations of not being a "real" Hungarian:

We all come from ancient Hungarian families and all our relations bear genuine Hungarian family names. Their occupations were extremely varied: artisans, farmers, shepherds, churchmen, businessmen, army officers, civil magistrates, parish priests, bank clerks (Mindszenty 1974, 1).

Looking back and narrating his life, the 82-year old Cardinal considered it important to begin with a clear definition of his national identity, referring to his family background. Why was it so important for him to emphasize his and his family's Hungarianness? As long as Joseph Pehm had been active in the little town of Zalaegerszeg, where he spent 25 years as priest of the town church, he seemed not to have had to concern himself much with the question of his family name. Zalaegerszeg was over 90 per cent Catholic, but ethnically mixed. As soon as he became more and more involved in nationwide conflicts, he might have considered it better to magyarize his name. His family name Pehm could have been used to denounce him as someone who was not "really" Hungarian. Whatever his motives, his decision, taken at a time of violent national conflicts, clearly indicated that he wanted to be identified with the Magyars and not with the German minority, which was sizeable in the south-western part of the country.

At the time, it was hardly rare to magyarize a family name, especially one that sounded German or Slovak. Between 1815 and 1956 some 300,000 Hungarians applied to change their family names, 95 per cent of them from a foreign sounding name to a Hungarian one (Kozma, 2000). There is even a Hungarian word for the magyarization of names: névmagyarositás. This affected almost 500,000 people, mostly of whom were Jewish. Other groups included Catholic Slavs and German 
Catholics or Lutherans. Many Hungarian Germans (and Slovaks) had magyarized their names in the second half of the 1930s, but the bulk of them - unlike József Pehm - did it after the end of the Second World War, when the notion of the collective guilt of the Germans was internationally accepted.

But Pehm was the only higher Catholic cleric to magyarize his family name. Other bishops did not seem to have cared about their non-Hungarian names. During the interwar period, out of the forty-three Catholic bishops in Hungary, six had Czech or Slovak family names and eight had German names. The Archbishop of Esztergom and Primas Csernoch (1912-27) had a Slovak or Czech name, as did the bishops Smrecsányi (1912-43 Eger), Czapik (Eger 1943-56), Prohászka (Székesfehérvár 1905-27), and Shvoy (Székesfehérvár 1927-68). German names included Breyer (Győr 1933-40), Hanauer (Vác, 1919-42), Glattfelder (Csanád 1911-42), Lindenberger (Nagyvárad 1919-21), Brém (1921-23 ibid.), Scheffler (Szatmár 1942-48), Pájer (Rozsnyó 1928-37), and Fischer-Colbrie (Kassa 1939-48).

Mindszenty's decision to change his name may not have been an attempt to magyarize it so much as an attempt to aristocratize it. In his memoirs he claims that in 1733 one of his forefathers was granted the status of Hungarian nobility (Mindszenty, 1974; the Hungarian original refers to the "class of freemen," but the German edition explicitly says "Adelstand"). Pehm does not sound like the name of a Hungarian noble family, while Mindszenty does, especially with the suffix "y" (von) at the end. With the aristocratization of his name he might have wanted to emphasize his legitimism.

When Mindszenty was appointed bishop of Veszprém in March 1944, German troops occupied the territory of their 'last ally.' With the efficient help of the Hungarian bureaucracy, police, and Arrow Cross, the Germans soon started the deportation of about 400,000 Hungarian Jews, and the so-called "Holocaust after the Holocaust" began (Gerlach and Aly, 2002). In December 1948 Mindszenty wrote that as bishop of Veszprém he had intervened several times at the offices of the Prime Minister and the Minister of the Interior with regard to the "Jewish question" (Közi Horváth, 2002, 30). In his memoirs he states that the Hungarian Catholic bishops protested vehemently in June 1944 in a letter and that this letter helped to save the lives of most of the Jews who were in the Budapest Ghetto at the time (Mindszenty, 1974, 14-15). Whether this is true or not is another question. We know that several Catholic nuns (including Margit Slachta and Sára Salkaházi) and priests, as well as bishop Apor rescued Hungarian Jews, and also that the activities of Nuncio Angelo Rotta and a letter written by Pope Pius XII to Admiral Horthy influenced the Regent to bring the deportations to a halt. But we still know very little about Mindszenty's role in these actions. We know that on October 31st, 1944 he personally handed over a memorandum, signed by him and the other bishops of Western Hungary, to Szálasi's deputy. In this memorandum 
the bishops asked the leader of the Arrow Cross "not to turn the Western part of Hungary into a battleground" (Mindszenty, 1974, Doc 2, 252-3). A few days later, the bishop, together with seminarians and priests, was arrested by a local Arrow Cross leader. This imprisonment, his second after 1919, contributed considerably to Mindszenty's moral reputation after 1945 and might have been one of the reasons why some months later Pius XII appointed him to head the Catholic Church of Hungary.

In the last months of the war, the Churches also profited from the fact that they were the only remaining public institutions offering shelter, food and help to thousands of refugees or providing precious information to people who were searching for their relatives. Churches were overcrowded, and for many people the church symbolized the only sign of hope in a time of chaos and destruction. The image of the church as a bastion of peace and reconciliation, a stable "rock" in a sea of uncertainty, was communicated by the Christmas addresses of the Pope and the bishops in 1944, but this image was not to last for long.

What impact did the events of the Second World War and the Holocaust have on Catholic identity in Hungary? The discussion about the responsibility of the Catholic Church for the Holocaust is long and complex (Becker, 2005; Rubinstein, 2001; Sánchez, 2001; Zuccotti, 2000). The official standpoint of the Vatican and the opinion of the overwhelming majority of the bishops in Europe at the end of the war came in the context of a religious explanation of World War II and its consequences, including the murder of six million Jews, as the terrible outcome of the secularization of European societies. Mindszenty used this interpretation in a pastoral letter of May, 1945 (Mindszenty, 1974, 254):

\footnotetext{
We have suffered one of the most dreadful catastrophes in the history of this land. [...] We are all laboring to rebuild the ruins. But let us never forget that the ruin of our souls is far more tragic than the ruined cities we see all around us. Our people have lost respect for the laws of God. They have also lost that respect for authority which is a cornerstone of all civilized society. Our sufferings resulted from the failure of our leaders to observe our traditions and our ancient faith. There are many who believe that human beings, and in particular the government, have the right to violate divine laws whenever it seems expedient to do so. This kind of thinking caused innocent people to be interned in concentration camps, robbed of all their possessions, exiled or murdered outright. Those who issued and carried out such orders, or merely approved of them, all forgot one thing: whenever a conflict arises between human and divine law, we must obey God rather than men.
}

As in 1919, after the catastrophe re-Christianization, the "return to Christ," was seen as necessary for the sake of humanity, an opinion shared by many conserva- 
tive Protestants (Giers, 1977, 285; Klimó, 1998). The self-imposed mission of the defenders of the "Abendland" (Occident) had a double meaning. Particularly in Central Europe, it was not only an explanation of the past catastrophe, but also included a message addressed to the present and the future, an anti-totalitarian, and in the new constellation anti-communist appeal (Schildt, 1999). This ideological framework facilitated the white-washing of historical guilt of many ex-Fascists and ex-Nazis , which had the impact of integrating hundreds of thousands of former enemies of democracy into the new postwar systems, contributing to a reconciliation which did not took place after World War I (Mazower, 2000, 288).

The record of church representatives during the interwar years and during the war was ambivalent: a small minority of Catholic clergy saved Jewish lives, some sacrificing even their own. A smaller minority supported the Arrow Cross and other "race defending" movements and ideas, while most Catholics were bystanders. Even if, after the war, the Church would always refer to the small minority who saved the lives of Jews, it is clear that the horrors of the war cast a long shadow on European Catholicism and on Christianity in Europe in general. What was the long-lasting effect on Catholic identity? We still do not know.

\section{Cold War Catholicism: Cardinal Mindszenty the Martyr and Catholic Militancy, 1945-56}

1948 decisively changed the world in which Catholics lived. In Hungary the political struggle between Communists and Catholics dominated politics and everyday life more than in other countries. This is one reason why the case of József Mindszenty gained so much international media attention. But his personality and the support he received from Pius XII also contributed to him becoming a martyr and symbol of Cold War Catholicism. Before 1945 the Hungarian Catholic church had thrived, and Catholic Action had been a huge organization with around 1,000,000 people within its ranks, almost a tenth of the population. Equally important was the strong Catholic influence on higher and basic education (university faculties, schools) and on the press. All this changed dramatically between 1946 and 1948.

With only 22 percent of the votes, the Hungarian Communists became the strongest party in the elections in September 1947. But even this very modest victory rested on repressive means against their opponents, as well as fraud and the help of the Soviet Army. During the celebrations of the 100th anniversary of the national-liberal revolution of 1848 the Communist Party of Hungary passionately propagated new historical interpretations and representations of the revolutions, which they depicted as the expression of one-hundred years of fighting for the freedom of their nation. Lajos Kossuth and Sándor Petőfi became central figures 
for their Stalinist national history narratives. Apart from this "genealogical appropriation" (Verdery, 1997), the Communists also reinvented existing folk traditions for their own propaganda, a strategy they adopted from Soviet Stalinism (Klimó, 2003; Klimó, 2007a).

The campaigns propagating a national communist understanding of Hungary's past were directly linked to aggressive attacks on Catholicism, the church, and its representatives in general, leading to the staged trial against Cardinal Mindszenty in the beginning of 1949. In December 1948 the Communist leaders arrested the Cardinal and staged a show trail against him. After he was interrogated and tortured, Mindszenty was sentenced to life imprisonment on the basis of accusations that he had planned to reestablish the Habsburg Empire with U. S. and British help (Mindszenty 1989, 123). He was in prison until the fall of 1956, when, shortly after the uprising against the Stalinist system, a group of revolutionary officers and soldiers freed him and brought him to Budapest. On November 3, 1956 the Cardinal delivered a short speech which was broadcasted by the Hungarian national radio. When Soviet troops returned and took control of Budapest and the rest of the country again, Mindszenty found asylum in the U. S. Embassy in the Hungarian capital, where he was to spend the next fifteen years.

One of the main accusations of the People's Court in Budapest against Mindszenty during the show trial of 1949 was that he "was engaged in the resurrection of Habsburg rule in Hungary" (Mindszenty, 1989, 123; Mindszenty, 1949). At the same time, the leading Stalinist historian Erzsébet Andics "unmasked" the primate of 1848/49, János Hám, as a national "traitor" and "enemy of the Hungarian people" (Andics, 1948). Stalinist ideology divided past, present and future into unchangeable "progressive" and "reactionary" tendencies, and in this schematic view the higher clergy obviously belonged to "reaction" (Klimó, 2007a).

Already during the years before the trial against Mindszenty, the strong Catholic Action of Hungary was partly destroyed and had to endure numerous discriminating measures enforced by the communist controlled police and Soviet military administration. Thousands of Catholic schools were nationalized and hundreds of Catholic youth, women's, men's, and agrarian workers' and other associations were dissolved. The Catholic press and publications were censored and reduced to a minimum. Active priests and laymen were arrested and Church property was confiscated. This massive campaign, aiming to destroy the economic and social basis of Hungarian Catholicism, began with the Land Reform Act of 1945, which targeted the Church as the richest land owner and was brought to an end only in 1989.

In these years, Pius XII began to condemn communism explicitly. A true Catholic, as defined by the Pope, could no longer be neutral in this struggle between the Church and its enemies. The appointment of Mindszenty indicated that the 
Pope wanted a "pugnacious Church leader" (Kent, 2002, 98). With the excommunication decree of 1949, which banned all members and even sympathizers of Communism from the sacraments, Pius XII enforced this identification of Catholicism with anticommunism. It should be stressed, however, that this decree was not used against thousands of Catholic members or sympathizers of Communist parties worldwide, but almost exclusively against priests who collaborated with the Stalinist regimes. The few examples include the leaders of the so-called "priests of peace" movement (which was controlled by the Hungarian secret police), who were excommunicated in 1950 and 1958 (Bottoni, 2008, 151, 163).

The Pope was aware not only of the possibilities offered by film and radio for mass communication, but also of the power of the images of mass gatherings (Valli, 1999). The new image of the Catholic layman was that of a loyal and disciplined soldier who would unite with other Catholics on the street to fight against the red threat. Pius XII and other Church leaders, like Cardinal Mindszenty, successfully mobilized Catholic Action and hundreds of thousands of believers. St. Peters square in Rome became a sea of green berets, the caps of Catholic Action, when hundreds of thousands of members celebrated the historic victory of the Democrazia Cristiana in April 1948 against the parties of the left (Piva, 2003). The mass gatherings had a strong emotional impact on some Catholic activists. As one of them later recalled, "I don't remember what Pius XII was talking about, but I remember well the enthusiasm with which we listened to his speech" (Piva, 2003, 29).

The image of a disciplined unified front of Catholic lay organizations under the balcony of Pius XII was appealing to Catholics all over the world. Cardinal Mindszenty followed this example. In 1947 he declared a year of celebrations dedicated to the Virgin Mary as Patroness of the Hungarian nation. The Cardinal referred to the great success of mobilization during the Eucharistic World Congress of 1938 in Budapest, when Eugenio Pacelli, the Vatican legate who became Pope Pius XII one year later, was celebrated by hundreds of thousands of Catholics from all over Europe (Gergely, 1988). On August 20th, 1947, in a speech addressed to the some 500,000 people who had followed the procession of the Holy Right (Hand relic) of King Saint Stephen, Cardinal Mindszenty declared:

\footnotetext{
Saint Stephen is the best symbol of our one thousand year old past. From him our nation received the greatest and eternal values: the holy mother church, the veneration for St. Mary and a Christian education. Let us proudly protect the tradition of Saint Stephen in the family and in society, so that it will help us to resurrect the dying Hungary (EPL).
}

Another important aspect of the re-invention of Catholic identity in the Cold War campaign was the characterization of the Church as a bulwark of traditional 
family values and certain gender roles in a "battle for purity" (Tonnelli, 2003). In short, Catholic identity, as constructed by Church leaders immediately after 1945, focused on unity, discipline, authority, and tradition.

As the head of the Catholic Church in Hungary, Mindszenty was a prominent figure of international media. Media attention concerning the Cardinal reached its peak in 1949 during the show trial. TIME Magazine dedicated a cover to him in the February 14th issue of that year (see below). In 1956 and 1974 he was again in the spotlight for a short time. He himself was aware of the fact that he had become a media personality. The Preface to his Memoirs (1974) begins with a short description of the British movie, "The Prisoner" (1955). In this film, Alec Guinness, who after the film converted to Catholicism, played a Cardinal who had been imprisoned and tortured, a figure modeled on Mindszenty. József Mindszenty commented,

This film was given a friendly reception by the critics and the public and was shown throughout the world. But I am sorry to say that the well-meaning script writer did not know Hungary's communist prisons, and so the movie failed to give any picture of reality. [...] In retrospect events often tend to be given quite a fantastic cast in yellow, white, and black books, or in films. [...] In my memoirs I want to show the reality as it was (Mindszenty, 1974, xxvii-Xxviii).

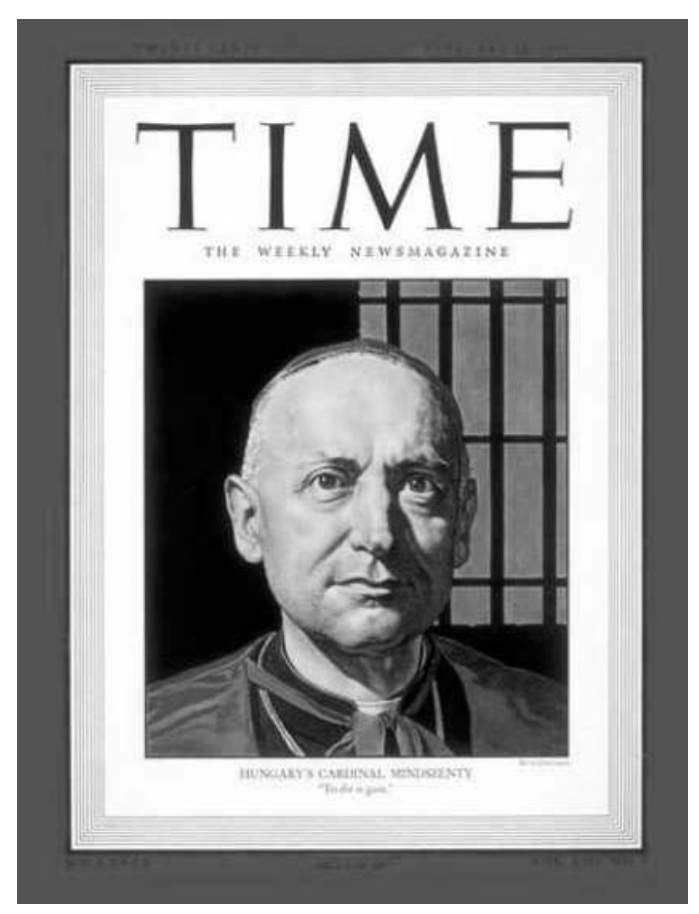


The Cardinal made no mention of "Guilty of Treason" (USA, Felix E. Feist, 1950), the first motion picture, a kind of Cold War B-movie, to borrow its plot from the story of his trials. In this first Mindszenty-movie a Soviet advisor convinces the Hungarian communists that they should allege that the straightforward bishop, who had been active in the resistance against the Nazis, was in reality an antisemite. This referred to the propaganda campaign launched by the Communists in an attempt to blame Mindszenty not only for planning a coup against the Hungarian republic with the aim of restoring Habsburg rule, but also of being antisemitic, trying to relate him closely to the Horthy regime and its Christian national ideas.

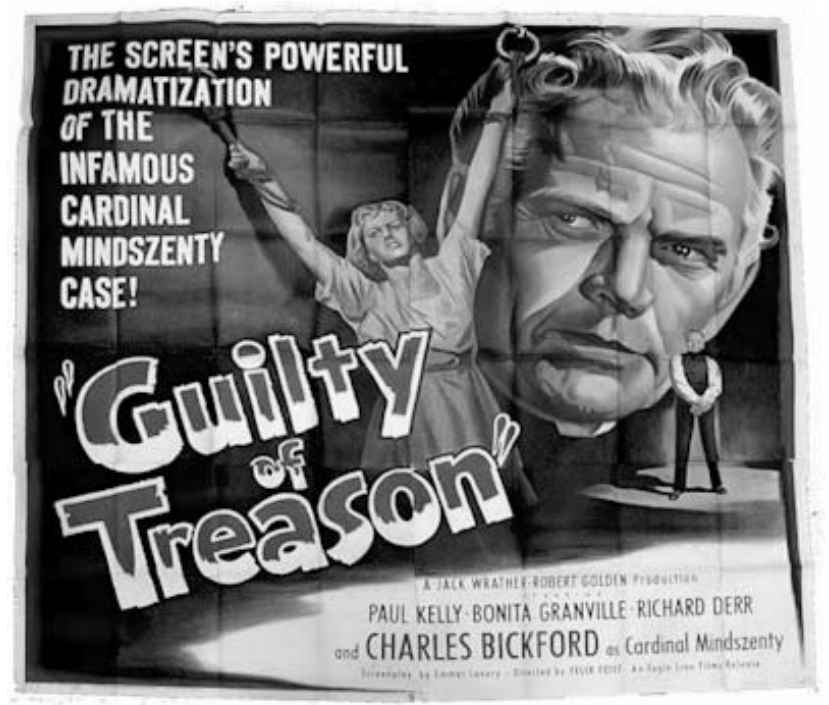

What impact did persecution and later the State control over the church have on Catholic identities in Hungary? After the imprisonment of Cardinal Mindszenty and of other high ranking clergy in the early 1950s, the Catholic Church hierarchy in Hungary was forced to sign an "agreement." In this the Church leaders had to declare publicly their political loyalty to the Communist State and renounce the continuation of youth education outside the very restricted limits defined by the law. All this aimed at the removal and marginalization of religious life from the public sphere. Pius XII was outraged, because he considered the signing of the "agreement" a violation of Canon law, damaging the unanimity of the Catholic Church (Riccardi, 1992, 149). In fact, the communists put Mindszenty on trial specifically as an attempt to remove a stubborn and intransigent follower of the Vatican who had not proven at all willing to negotiate with the Communists. Before Stalin's death in 1953 repression in Hungary reached a peak. Most of the 
male and female orders were dissolved in 1951. Hundreds, if not thousands of priests, nuns and monks were arrested, imprisoned, or sent to labor camps. Catholic discourse lost a great deal of its institutional space. The only Catholic newspaper left, Új Ember (New Man), was reduced from a daily to a weekly paper and was controlled, censored and marginalized. The State security tried to build up the afore-mentioned "peace movement" of priests (Orbán, 1996). In the turbulent weeks of late October and early November 1956, most of the "peace priests" were chased away by their communities. Even if it could not be discussed in public, polarization between the Catholic clergy who remained loyal to Rome and the (few) priests who were compromised by their cooperation with the Communists was visible. The framework in which Catholic identities were developing during the 19th and 20th centuries had changed dramatically during the first decade after the end of World War II.

\section{A New Catholicism in Hungary? The Case of Regnum Marianum during the 1960s}

The dissolution of monasteries and other Catholic institutions, as well as the "production" of martyrs by the repressive State, seems to have strengthened religious identities and devotion to the intransigent, ultramontane orientation in Communist Hungary of a minority of believers. People became more devout than they had been before, particularly children from déclassé families (former elite and middle class background). When reading the impressive book by writer Péter Esterházy on his father, who worked as a secret informer for the state security forces, the important role of Catholic belief and practice in this aristocratic family, with its almost mythical history, becomes vivid (Esterházy, 2002). An excellent oral history study on Catholic believers was recently published by sociologist Zsuzsanna Bögre (Bögre, 2004). Bögre found out that not only former elite or former clergy, but also members of the marginalized low social strata, such as agrarian workers, tended to stick to their Catholic identity much more often than those who experienced the radical social changes of the 1950 s as a social advancement. Those who profited from the new socialist order were more willing to adapt to the new values and ideals propagated by the State. Bögre also distinguishes between different generations.

More specific and less generalizable is the case of Regnum Marianum, a small group of priests belonging to a community, an oratory, founded around 1896 to live according to the social reform ideas of bishop Ottokár Prohászka (Dobszay, 1991). In the fall of 1951 the movement was suppressed and its college in Budapest dissolved. Despite persecution by the police and state security forces, work in the field of Catholic education of young people, mostly from middle or working 
class background, continued. Regnum Marianum was a result of Catholic intellectual renewal and a reaction to 19th century anti-Catholic liberalism. Its activities focused mostly on the higher education of talented boys from poorer families. According to the chronicler of the movement, János Dobszay, Regnum priests, while they also liked excursions and hiking in the woods and hills around Budapest, distanced themselves from the "militarist" spirit that had dominated the Catholic Scout movement in the first half of the 20th century. In the 1930s they dissolved their youth groups because they did not want them to be united with the semi-fascist "Levente" (ABTL, Regnum 91). After the dissolution of the movement in 1951, Regnum priests continued with excursions. These activities turned out to be a very successful way of maintaining and even expanding a network of small Catholic youth groups. Although the secret police observed their activities and arrested some of the priests in 1960, 1963-64 and 1970, this work was continued until 1989. Hungarian secret police could never trace all of these hundreds of illegal youth groups, as later turned out. The priests of Regnum Marianum also tried to modernize their work permanently. Their communities consisted of non-hierarchical small units which acted with the silent approval of the church. Bishop Endrey, president of the small remaining Catholic Action, supported a range of different youth group networks without calling the attention of the regime to his endeavors (ABTL, Endrey, 23f.). Within these groups, a renewal of Hungarian Catholicism was vividly discussed. In February 1960, a group of "Regnumists" met to discuss the current situation of the church and possible alternatives (ABTL Regnum, 100-1). They heavily critized Church discipline, it having "always [been] an illusion" (ibid. 101). The paper proposed a renovation, a looking forward to the future: "We should not fall behind the intellectual development of our time" (ibid.) Priests should know much more about contemporary science, art, literature. We know from the reports of the secret police that the Regnum priests went to considerable effort to realize these goals. They read and exchanged all kinds of books and articles on Catholic reform, such as the books by Jacques Maritain, the influential La France, pays de mission, and books on intellectual trends in general, including translated and copied texts which seemed important to them. They also organized talks and little seminars on an array of subjects.

Can this self-critical mood among a tiny minority of young and active priests be understood as a reaction to the state controlled media and public sphere in communist Hungary? They may have had an influence, but one finds similar changes in the attitudes of many priests and Catholic activists as well, in many other countries in Europe and Latin America since the 1950s (Linden, 2009). Until 1956, Pius XII stressed the importance of the firmness of the anticommunist block as a second ,antemurale christianorum“ against the Soviet danger, celebrating masses for the martyrs of Poland and Hungary. When the Hungarian uprising, praised by the Pope, was crushed by Soviet troops, Pius seemed to become disillusioned with 
the Western world, which failed to intervene. After his death, many Catholics were tired of the permanent political mobilization. The concept of triumphalism seemed to have lost its strength. Pius XII himself warned in 1953 that Catholic education had to be more profound and be based on a deeper and voluntarily acquired knowledge (Piva, 2003, 142).

The example of Regnum Marianum and the changing historical background of the 1950s and 1960s indicate that the renewal of Catholicism and Catholic identities was not restricted to Western countries alone, although the situation of Catholics and Christians in Eastern Europe remained different.

\section{Vatican Ostpolitik, Vatican II, and Catholic Beat Masses: Mindszenty Surpassed by History? (1964-75)}

In 1971, the Vatican, the Hungarian and the U. S. governments agreed on a way to make possible the Cardinal's exile to the West. It was a humiliating process, because Casaroli, the Vatican emissary, made promises to Mindszenty he was unable to keep, and the Cardinal found himself helpless regarding the pressure from the Vatican, the Hungarian government, and the State Department. He spent the last years of his life in Austria, after having traveled extensively to the U. S., Latin America and Western Europe. Mindszenty and his very conservative and anti-liberal ideas and loyalty to the Habsburgs did not seem to fit into the radically changing world of the 1960s and 1970s. Industrialization, migration, urbanization, and the dissolution of agrarian structures and ways of life which had helped to conserve a certain traditional Catholicism accelerated over the course of these decades, both in Hungary and beyond its borders. But interpreted as an opening up of the church to modern life, Catholic doctrine and practice, as decided by the Second Vatican Council (1962-65), further contributed to the dissolution of the old Catholic self-understanding as a bulwark against modernity. Under John XXIII and Paul VI Vatican policy towards communism also changed, especially with regard to "Pacem in Terris" and the first agreement of the Vatican with a communist state, which was Hungary, in 1964. The agreement came at a very high price, excommunicated priests, who collaborated with the Communist dictatorship, were elevated to bishops and the Hungarian bishops' conference was more and more taken over by agents of the Hungarian state security, as were Catholic seminaries, the Catholic press, etc.

Cardinal Mindszenty aged over the course of his fifteen year exile inside the Budapest Embassy of the U. S. He did not participate in the radical changes of Catholicism, but focused more and more on his own personal fate. Changes in Vatican strategy towards communism added to the isolation of the Hungarian Primate. 
According to Stefano Bottoni, Paul VI focused more on Poland, which made sense, because the Polish Catholic Church was much stronger than the Hungarian.

But it was not so much Catholic diplomacy or Communist control of the church that contributed to the changes in Catholic identities and the isolation of Cardinal Mindszenty, but rather the radical cultural and social changes which took place in society. One sign of these changes was the introduction of pop music into the Catholic mass, which occurred in the late 1960s.

On 28 April 1966, hundreds of people, mostly youths, gathered in the Sala Borromini in the Oratorio S. Filippo Neri in Rome to attend a concert which very soon became a sensational news story in other countries: the "Missa Iuventutis," for vocals, electric guitar, bass, piano and drums, arranged by film music composer Marcello Giombini and the beat band "The Barritas" (Matteucci, 1966). Two weeks later, the Hungarian illustrated weekly Tükör (Mirror) informed its readers in detail about this "Jé-jé mass" in Rome, adopting the term Walter Ulbricht had used with regard to beat music in the German Democratic Republic (Rauhhut, 1993). The article tried to depict the event as scandalous. Some teenagers had started to dance the "shake" and applaud "in an American way" by clapping their hands and whistling shrilly. "Youngsters rampaged and yelled as if at a boxing fight. [...] A window was broken" (Új Ember June 5th, 1966, 3). Beat masses in Catholic churches soon became hip. Beat, "teenage", or youth masses were celebrated in many parishes in Italy, Germany, the United States, and other countries. The first Hungarian beat mass was composed by 16-year old Imre Szilas and performed for the first time in the small town of Abony at Easter 1967. In May 1968 his beat version of Latin liturgical texts was even broadcast by Hungarian and Austrian state television (Kenyeres, 2002, Népszabadság, May 28th, 1968).

The history of beat masses of the 1960s and 1970s still remains to be written. It was a very popular movement in West and East Germany, Poland, Italy, France, The Netherlands, and probably other parts of Europe as well. Particularly fascinating is the extreme change in the image of the Catholic Church represented by this movement. Even if many Catholic conservatives protested and some bishops found ways to prevent similar performances of "night club music" in "the sacred house of God," the very fact that electric guitars were being played by long haired "hippies" inside church buildings signified a new spirit and attitude of many (not always younger) priests and communities all over the Catholic world, which only a few years earlier would have appeared absolutely impossible, especially if one keeps in mind that Cardinal Mindszenty himself regarded young people dancing as an invitation to sin. There was a huge gap between the representations of the body in the 1940s, Catholic scouts with their "militarist" discipline, and the body of the individualist, hedonistic physicality of the teenager in the 1960s (Rónay, 2). The vicar of Rome was also infuriated about the "orgiastic shouting" which was 
heard during the performance in the Oratory of S. Filippo Neri in April 1966 (Sansoni, 2002, 225-6).

A second aspect worth mentioning regarding beat masses is that of all the Catholic churches in the world, the conservative Hungarian church seemed to have promoted beat masses with some enthusiasm. This may well be because some police and communist party officials had been shocked by the images of hundreds, if not thousands, of young people flocking into churches on Sunday. They arranged big beat concerts at the same time when beat masses had been planned, and they started a major propaganda campaign in the official media. Even Péter Nádas, one of Hungary's greatest contemporary writers, participated in this campaign, writing articles about beat masses in which he wanted to show that the teenagers were not really interested in the Catholic faith, but rather in the music. He also sought to demonstrate that the staging of big concerts such as the one held in May 1968 in the Mátyás-Church in Budapest was "dangerous and irresponsible" on the part of the organizers (Nádas, 1968a; Nádas 1968b).

Új Ember, the Catholic weekly, reported and commented on beat masses in a much more positive way. On June 5th, 1966 a commentator, writing about the first beat mass in Rome, contended that "this performance, which almost degenerated into a scandal, should, however, be seen from the perspective that the interpreters and the fans of modern music - also in the field of entertaining music - are looking for a meeting with faith and the church" (Új Ember, June 5th, 1966, 3). At the same time the possibilities offered by the church were very attractive to young beat fans in Hungary because they knew that "the state surely didn't appreciate it" (Szigeti interview). In Hungary, the beat movement had far more support from middle-class youth than it did in Western Europe. These youths were mostly students in grammar schools, especially in the few Catholic schools still allowed by the communist state to function. In these middle-class circles, Western influences and fashions enjoyed a much higher value than they did in the West itself, because they were also, along with religion, regarded as something the communists did not like. In May 1968, in an interview with Új Ember, Imre Szilas, the composer of the first Hungarian beat mass, a man who later escaped to the West and settled in California, where he continued his studies in music and also became an active member of a Catholic church community, explained his motivations:

\footnotetext{
The goal of my mass was to translate the message into the language of beat music speaking to the beat fans. I showed the joy of faith God's mercy signifies for me. This is also devotional music, but of course a totally different devotional music than what my parents listen to. (Új Ember, May 12th, 1968, 3.)
}

This was the voice of a new generation of individualistic, self-confident, and modern young Hungarian Catholics. Some of them found their way to the youth 
groups organized by the Regnumist fathers (ABTL, Hagemann file). The World of Catholicism and world Catholicism seemed to explode in thousands of different directions.

\section{Epilogue: József Cardinal Mindszenty as Lieu de Mémoire after 1989}

Cardinal József Mindszenty was forced to resign officially on December 18th, 1973. He died less than two years later in Vienna, on May 6th, 1975. Mindszenty was buried in Mariazell, an old pilgrimage site, supported and frequented by the Habsburg family, about one hour's train ride west of Vienna. His wish to be buried there confirmed his enduring loyalty to the house of Habsburg. On the other hand, Mariazell was also considered a holy site of the Catholic branch of the Hungarian national movement (as well as of other national movements) in the 19th century. In 1856, while the 700th anniversary of the pilgrimage site of Mariazell was being celebrated, one of Mindszenty's predecessors welcomed 30,000 Hungarian pilgrims, all dressed in red, white, and green (Frank, 2009). It was a place that represented not only the traditions of the Habsburgs, but also the traditions of the Hungarian movement for national independence. Ten years after Mindszenty's death, U. S. President Ronald Reagan, who was born to a Catholic family but baptized a Disciple of Christ in 1922, referred to Mindszenty as "a symbol of courage and faith" (OSA). The Cardinal had already become an icon when the wall came down. After 1978, Pope Paul VI and the people who had complained about the stubbornness and unwillingness of the Cardinal to adapt to the changes of the times were now themselves regarded as relics of times past. During the Second Cold War, which started with the election of a Polish Pope and the Soviet invasion of Afghanistan, anti-Communist heroes like Mindszenty were reevaluated. In Hungary, Catholicism, like nationalism, underwent another transformation and became attractive for many social groups and people who wanted to express their distance from the declining Communist regime and everything related to it.

\section{Acknowledgements}

I would like to thank my friends, colleagues, and students from the University of Pittsburgh for their help in discussing and editing this article, particularly Irina Livezeanu, Lisa Seibert, Andrew Behrendt, and Victoria Harms. All remaining errors and shortfalls are mine. 


\section{References}

Archival Sources:

Állambiztonsági Történelmi Levéltár (ABTL - Historical Archive of State Security), O-11516/1, BM I/2-b, Objektum dosszié, Regnum Marianum.

ABTL, BM oszt. I/2-b, Személyi dosszié, sz. 10-31255, Endrey Mihály (Personal file of Bishop M. Endrey) O-12302/2.

ÁBTL: BM III/1, Vizsgálati dosszié, "Hagemann Frigyes és társai” (Investigation File against "Frigyes Hagemann and Co.")

Esztergomi Prímási Levéltár (EPL), 5583/1947, p. 3.

Open Society Archive online: http:/www.osaarchivum.org/files/holdings/300/8/3/text_da/ 37-2-42.shtml (article about Mindszenty's legacy in Hungary and the USA, 1985)

Osservatore Romano

Radio interview with István Szigeti, one of the beat mass enthusiasts: www.vedrescsaba.hu/ magyar/sajto/petofi2005.htm (March 23rd, 2010)

Tükör (Hungarian illustrated magazine)

Új Ember (Hungarian Catholic Weekly)

\section{Bibliography}

Adriányi, Gabriel and Kloczowski, Jerzy (2006) 'Catholic Nationalism in Greater Hungary and Poland', in Sheridan Gilley (ed.) World Christianities c. 1815-c. 1914 (The Cambridge History of Christianity, Vol. 8) (Cambridge: Cambridge UP).

Adriányi, Gabriel (2003) Die Ostpolitik des Vatikans 1958-1978 gegenüber Ungarn. Der Fall Kardinal Mindszenty (Herne: Schäfer Verlag).

Aly, Götz and Gerlach, Christian (2002) Das letzte Kapitel. Der Mord an den ungarischen Juden (Stuttgart: Deutsche Verlags-Anstalt).

Andics, Erzsébet (1948) 'Az egyházi reakció 1848-49-ben', in Forradalom és szabadságharc (Revolution and Freedom Fight 1848-49) (Budapest), 315-413.

Becker, Winfried (2005) 'Papst Pius XII. und sein „Schweigen“ über den Holocaust' Kirchliche Zeitgeschichte, Vol. 18, No. 1, 40-67.

Bjork, James (2007) 'Beyond the Polak-Katolik. Catholicism, Nationalism, and Particularism in Modern Poland', in Urs Altermatt and Franziska Metzger (eds) Religion und Nation (Stuttgart: Kohlhammer), 97-119.

Bögre, Zsuzsanna (2004) Vallásosság és identitás. Élettörténetek a diktatúrában (1948-1964) (Budapest and Pécs: Dialog Campus Kiadó).

Bottoni, Stefano (2008) 'A Special Relationship. Hungarian Intelligence and the Vatican, 1961-1978. NKVD/KGB Activities and its Cooperation with other Secret Services in Central and Eastern Europe 1945-1989', in Anthology of the international and interdisciplinary Conference. Bratislava, Nation's Memory Institute.

Bottum, Joseph and Dalin, David G. (2004) The Pius War. Responses to the Critics of Pius XII (Lanham).

Casanova, José (1994) Public Religions in the Modern World (Chicago and London: The University of Chicago Press).

Casaroli, Agostino (2007) The Martyrdom of Patience. The Holy See and the Communist Countries (1963-1989) (Ave Maria Centre of Peace). 
Csonka, Emil (1976) The Exiled Cardinal (San Francisco: Uj Europa).

Dobszay, János (1991) Így vagy sehogy! Fejezetek a Regnum Marianum életéböl (Like this or not at all! Chapters from the life of R. M.) (Budapest).

Esterházy, Péter (2002) Javitott kiadás: melléklet a Harmonia caelestishez (Budapest: Magvető [2nd ed.]).

Fejérdy, András (2006) 'Mindszenty József szellemi portréja’, Kommentár, No. 4, 43-54.

Fejérdy, András (2009) 'Aranykalitkából láthatatlan bilincsek közé. Mindszenty József az emigrációban’, Kommentár No. 1, 115.

Frank, Alison (2009) 'The Pleasant and the Useful: Pilgrimage and Tourism in Habsburg Mariazell', Austrian History Yearbook, Vol. 40, 157-82.

Gergely, Jenő (1988) Eucharisztikus világkongresszus Budapesten 1938 (Budapest).

Geulen, Christian (1999) 'Die Metamorphose der Identität. Zur „Langlebigkeit“ des Nationalismus', in A. Assmann and H. Friese (eds) Identitäten. Erinnerung, Geschichte. (Identität 3) (Frankfurt am Main: Suhrkamp (2nd ed.)), 346-73.

Giers, Joachim (1977) 'Humanismus und christliche Ordnungsidee nach den Weihnachtsbotschaften Pius' XII', in Herbert Schambeck (ed.) Pius XII. zum Gedächtnis (Berlin: Duncker \& Humblot), 281-308.

Göncz, László (2005) 'A területi integritás szellemében. Pehm (Mindszenty) József megnyilatkozásai a visszacsatolt Muramentéről és Muraközről', Vasi Szemle No. 4, http://www. vasiszemle.t-online.hu/2005/04/goncz.htm (April 11th, 2010).

Graham, Robert A. SJ. (1996) The Vatican and Communism in World War II. What Really Happened (San Francisco).

Hanebrink, Paul (2009) In Defense of Christian Hungary (Paperback edition) (Cornell UP).

Hatos, Pál (2006) ‘A Mindszenty-örökség értelmezései 1989 után’, Kommentár, No. 4, 55-69.

Hóbor, József (1997) 'A keresztényszocializmus, mint eszme és ideológia Pehm (Mindszenty) József zalaegerszegi évei alatt’, Polvax. Társadalomtudományi Folyóirat, No. 1. http://www.pszfz.bgf.hu/konyvtar/polvax/p-97-1/6hobor.pdf (April 11th, 2010).

Kenyeres, István (2002) 'A superman hippik és a tanácstalan rendörök', in György Majtényi and Orsolya Ring (eds) Közel-Múlt. Húsz törénet a 20. századból (Budapest: MOL), 135-54.

Kertzer, David I. (2001) The Popes Against the Jews. The Vatican's Role in the Rise of Modern Antisemitism (New York: Alfred A. Knopf).

Kent, Peter C. (2002) The Lonely Cold War of Pope Pius XII: The Roman Catholic Church and the Division of Europe, 1943-1950 (Montréal: McGill-Queen's University Press).

Kirby, Dianne (2003) 'Religion and the Cold War - An Introduction', in id. (ed.) Religion and the Cold War (Houndsmills: Macmillan), 1-23.

Klimó, Árpád v. (1998) 'Kampf um die nationale Geschichte. Auseinandersetzungen zwischen Kirchen und Kommunistischen Parteien in Ungarn und der SBZ (1945-48/49)', in Kurt Imhof (ed.) Kommunikation und Revolution (Zurich: Seismo), 359-89.

Klimó, Árpád v. (2003) Nation, Konfession, Religion. Die ungarische nationale Geschichtskultur in europäischer Perspektive (München: Oldenbourg).

Klimó, Árpád v. (2007a) 'Helden, Völker, Freiheitskämpfe. Zur Ästhetik stalinistischer Geschichtsschreibung in der Sowjetunion, der Volksrepublik Ungarn und der DDR', Storia della Storiografia, Vol. 52, 83-112.

Klimó, Árpád v. (2007b) ‘A katolikus önértelmezés új irányai az 1960-as években Olaszországban és Magyarországon: Don Lorenzo Milani és Bulányi György példája’, Századvég, Vol. 44, $131-63$.

Klimó, Árpád v. (2008) 'Katholische Jugendgruppen in Ungarn in der zweiten Hälfte der sechziger Jahre. Die Gruppen um Regnum Marianum - ein religiöses Netzwerk?', in Annette Schuhmann 
(ed.) Vernetzte Improvisationen. Gesellschaftliche Subsysteme in Ostmitteleuropa und in der $D D R$ (Köln, Weimar and Wien: Böhlau), 121-37.

Közi Horváth, József (2002) Mindszenty Bíboros (Cardinal Mindszenty) (Budapest: Magyarorszsági Mindszenty Alapítvány).

Kozma, István (2000) ‘A névmagyarosítások története. A családnév-változtatások’ (The History of the Magyarization of Names. Changing Family Names). Historia, Nos. 5-6. http://www.historia.hu/archivum/2000/000506kozma.htm (March 19th, 2010).

Linden, Ian (2009) Global Catholicism. Diversity and Change since Vatican II (New York: Columbia UP).

Malmborg, Mikael af and Stråth, Bo (2002) 'The National Meanings of Europe', in id. (ed.) The Meaning of Europe (Oxford and New York: Berg), 1-25.

Matteucci, Benvenuto (1966) 'La musica, il canto ed il Concilio', Osservatore Romano, May 11th, 3.

Mazower, Mark (2000) The Dark Continent. A History of Europe in the 20th Century (New York: Vintage).

Mindszenty, Joseph Cardinal (1974) Memoires (New York: Macmillan).

Mindszenty József a népbiróság elött (1989) (Budapest: Pannon).

Mindszenty, Jozsef (1949) Weissbuch. Four Years of Struggle of the Church in Hungary (London).

Nádas, Péter (1968a) 'Beat Mise', Pest Megyei Hírlap, May 31st, 3.

Nádas, Péter (1968b) 'Beat Mise', Szolnok Megyei Néplap, May 14th, 8.

Niethammer, Lutz (2000) Kollektive Identität: Heimliche Quellen einer unheimlichen Konjunktur (Reinbek bei Hamburg: Rowohlt).

Niethammer, Lutz (2003) 'The Infancy of Tarzan', New Left Review, 19 (January-February). Available at: http://www.newleftreview.org/?view=2433 (March 13th, 2010).

Orbán, József Gyula (1996) Friedensbewegung katholischer Priester in Ungarn, 1950-1956 (Budapest).

Paksy, Zoltán (2004) 'Nagypolitika kicsiben: parlamenti választás és társadalmi háttere Zalaegerszegen 1935-ben' (Grand Politics from a Small Perspective: The 1935 Parliamentary Elections and their Background in Zalaegerszeg), Korall, Vol. 17, 88-106.

Piva, Francesco (2003) "La gioventú cattolica in cammino..." Memoria e storia del gruppo dirigente (1946-1954) (Milan: Franco Angeli).

Rauhut, Michael (1993) Beat in der Grauzone. DDR-Rock 1964 bis 1972. Politik und Alltag (Berlin: Basis-Druck).

Riccardi, Andrea (1992) Il Vaticano e Mosca 1940-90 (Roma and Bari: Laterza).

Rónay, György (1968) ‘Ezzel szemben’, Új Ember, 25 February, 2.

Rubinstein, Richard L. (2001) 'The Vatican Statement on the Shoa and Pius XII', in John K. Roth and Elisabeth Maxwell (eds) Remembering for the Future. The Holocaust in an Age of Genocide Vol. 2 (Houndsmills: Palgrave), 455-80.

Sánchez, José (2002) Pius XII. and the Holocaust. Understanding the Controversy (Washington DC: The Catholic Univ. of America Press).

Sansoni, Virginio (2002) La musica nella liturgia. Note storiche e proposte operative (Padova: Edizioni Messagero), 225-6.

Schildt, Axel (1999) Zwischen Abendland und Amerika. Studien zur westdeutschen Ideenlandschaft der 50er Jahre (Munich: Oldenbourg).

Szabó, Csaba (2005) A Szentszék és a Magyar Népköztársaság kapcsolatai a hatvanas években (Budapest: Szent István Társulat - Magyar Országos Levéltár).

Szekfü, Gyula (1920) Három nemzedék (Three Generations) (Budapest).

Tonelli, Anna (2003) Politica e amore. Storia dell'educazione ai sentimenti nell'Italia contemporanea (Bologna: Il Mulino). 
URL: http://unipmn.academia.edu/StefanoBottoni/Papers/86674/A-special-relationship--Hungarian-intelligence-and-the-Vatican--1961-1978 (March 22nd, 2010)

Valli, Bernardo (1999) Il film ideale. I cattolici, il cinema e le communicazioni sociali (Milano).

Verdery, Katherine (1997) National Ideology Under Socialism. Identity and Cultural Politics in Ceausescu's Romania (Berkeley et al.: University of California Press).

Zuccotti, Susan (2000) Under His Very Windows. The Vatican and the Holocaust in Italy (New Haven and London: Yale UP). 